\title{
Slik kan sykepleiere motivere rusmisbrukere til et bedre liv
}

Rusmidler gir $\varnothing \mathrm{kt}$ risiko for ustabilitet $\mathrm{i}$

følelsesregisteret til brukeren. Sykepleiere kan hjelpe brukeren til å få det bedre med seg selv, ved å bruke mentaliseringsbasert miljøterapi.

\section{May Britt Stendal}

Spesialsykepleier i psykisk helsearbeid

Boliger psykisk helse og rus Bærum kommune, Regional sikkerhetsavdeling, Dikemark sykehus

Mentaliseringsbasert miljøterapi

Recovery

Rusavhengighet

Livskvalitet

\section{Hovedbudskap}

Formålet med denne artikkelen er å belyse sykepleierens mentaliseringskompetanse i møte med mennesker som viser rusavhengighet. Når sykepleier mentaliserer, og mentaliserer sammen med bruker, kan det trygge bruker og dempe vonde følelser og ubehag. God mentaliserende holdning fra sykepleier kan styrke mentalisering hos bruker, og det kan fremme recovery gjennom mentaliseringsbasert miljøterapi (MBT-M). 
Rusavhengige har ofte redusert livskvalitet, hvilket kan innebære få eller ingen venner og ubalanse i kosthold og sosiale interaksjoner (1). Rusmidler gir $\varnothing \mathrm{kt}$ risiko for ustabilitet i følelsesregisteret, slik at tristhet, angst, uro, sinne og aggresjon i større grad oppstår (2).

Jeg jobber med rusavhengige og blir ofte møtt med svært ulik grad av mentalisering hos bruker. Nederlagsfølelser kan føre til stadige tilbakefall hvor bruker velger å ruse seg vekk fra det vonde. Toleranse og forståelse for bruker er derfor viktig. Ettersom rusavhengige strever med impulskontroll og affektregulering, kan de lett miste besinnelsen og bli agiterte og truende. Dette kan lede til motoverføringer til personalet og være recovery-hemmende for bruker (2).

Artikkelen er basert på en fordypningsoppgave i rus og rusavhengighet. Egne erfaringer trekkes inn for å belyse forskjellige problemstillinger hos rusavhengige knyttet til mentaliseringssvikt. Litteratur er hentet fra blant andre Rydén og Wallroth om mentaliseringsbasert miljøterapi (3), Lossius' teorier om rusbehandling (2) og Skårderud og Sommerfeldts miljøterapibok (4).

\section{Mentalisering}

Mentalisering beskrives som evnen til å se seg selv utenfra, og se andre innenfra. Hvilket omhandler å forstå ulike forhold mellom individer. For å forstå hvorfor en selv og andre tenker og handler som en gjør, er mentalisering en helt avgjørende sosialkompetanse (4). Manglende mentalisering kan ofte føre til svart-hvitt-tenkning , misforståelser og feiltolkning. Ubehaget av fenomenene dempes av ulike rusmidler (2). Miljøterapi derimot er en felles betegnelse på all samhandling som utføres av personalet sammen med bruker, i et trygt miljø med mulighet for endring (4).

\section{Recovery}


Recovery omhandler hva som fremmer fysisk og psykisk helse hos bruker, samt brukers evne til å tilegne seg ny kunnskap for å håndtere nye livshendelser. Brukermedvirkning utøves for at individet skal mestre egne premisser og ressurser innenfor egne $\varnothing$ nsker og behov (8). Recovery presenterer utvikling som endringer gjennom holdninger, følelser, mål, verdier, roller og ferdigheter, som en personlig prosess (9).

\section{Miljøterapi}

Mentaliseringsbasert miljøterapi (MBT-M) handler om å prøve å forstå hvordan bruker tenker og føler samtidig som personalet ikke skal tenke for bruker (2). Arbeidsformen omhandler holdninger og forståelser overfor bruker. Personalet har en vennlig tilnærming som er nysgjerrig og inviterer bruker til dialog, fremfor en «bedrevitende» holdning (4).

Jeg ser at MBT-M handler om forskjellige tenkemåter, og at fokus ligger på det fellesmenneskelige, her og nå, og interessen for hva som foregår i tankene hos bruker.

Når personalet er nysgjerrig og viser interesse for brukers tanker, følelser og ideer, kan det skape motivasjon som fremmer recovery. Å erkjenne brukers oppfatning av ulike situasjoner, men også brukers livshistorier, er viktig (4). Når jeg viser forståelse av ulik opplevelse, hva som er årsaken til brukers tale og atferd, opplever jeg at det fremmer recovery hos bruker.

\section{Å skape trygghet}


Profesjonell opptreden og kompetanse gir trygghet til bruker. Det kan redusere usikkerhet, misforståelser og negativ affekt (5). Et eksempel fra praksis er hvor bruker tolker kravet om å avbestille legetimen selv som en avvisning, og håndterer de vonde følelsene ved å kjefte høylytt. Når personalet har en avslappende kroppsholdning, bruker tid til å lytte og snakker med rolig stemme, gjør det at bruker føler seg trygg og ivaretatt. Sammen med personalet gjenskapes mentalisering. Årsaker til misforståelser, negativ atferd og rusinntak dempes, og recovery kan fremmes. Ved å mentalisere på denne måten kan brukers evne til å se egen, men også andres atferd $\varnothing \mathrm{ke}$, som følge av en indre motivasjon (6).

Erfaringer viser at mentaliseringsevnen hos bruker fremmes fordi forståelsen for andre aspekter er motivasjon nok i seg selv, som gjør at bruker tar andre valg. Dette gir recovery, ettersom mentalisering sammen med rusavhengige styrker mentaliseringsevnen hos bruker i form av bedre affektregulering, ruskontroll og sosial funksjon (7).

Sosiale interaksjoner med mennesker utenfor rusmiljøet er elementære faktorer knyttet til recovery hos rusavhengige (1).

\section{«Forskere trekker frem motivasjon som et viktig element.»}

Forskere trekker frem motivasjon som et viktig element, som gir stegvis bedring, følelse av mestring, selvbestemmelse og relasjonsbygging. Både indre og ytre ressurser påvirker motivasjonen. Begrepene i denne sammenheng kan blant annet handle om bemanning, budsjett, struktur og blanding av pasienter med ulike diagnoser på samme bolig (ytre ressurser). På den annen side kan det dreie seg om pasientens tilstand, personalets ulike syn på oppfølgingen, betydning av miljøet ved boligen, diskrepans mellom intensjon og handling hos personalet (indre ressurser). I tillegg handler det om brukerens erfaring med og innflytelse på helsehjelp (1). 
Mine erfaringer ved å stille ulike spørsmål er at bruker gradvis reduserer sin mistenksomhet mot personalet, og gir personalet tillatelse til å utforske mer sammen med ham eller henne. Personalet kan dermed fremme recovery hos rusavhengige i lys av MBT-M, ettersom det gir trygge rammer, gode samtaler og relasjonsbygging. Og ikke minst blir bruker møtt på en vennlig og respektfull måte (5).

\section{Økt motivasjon}

Rusavhengige kan ha redusert livskvalitet som følge av dårlige levevilkår, redusert fysisk og psykisk helse og negativ effekt på nettverk. Å $\varnothing$ ke eller opprettholde motivasjon hos bruker, samt at personalet er tålmodige, empatiske og samarbeider om ulike intervensjoner, er derfor viktig (1).

Stendal påpeker bevisstheten rundt motoverføringer, at gode intensjoner kan skape irritasjon og frustrasjon hos bruker, som igjen kan smitte tilbake på personalet. Situasjonen kan dermed utvikle seg i negativ retning, fordi mentaliseringen svekkes hos både bruker og personalet (5).

Dette gjenspeiler egne erfaringer hvor bruker blir nektet sin metadon fordi han er synlig beruset. Bruker roper høylytt og er truende mot personalet. Personalet føler seg utrygg og kjefter tilbake. En klassisk mentaliseringssvikt, som hemmer recovery. Denne atferden er brukers måte å uttrykke seg på når det kommer til følelser. Det er her MBT-M kommer inn, som gjør at personalet kan forvalte denne informasjonen på en riktig måte i møte med bruker. Fokus vil da handle om riktig helsehjelp for å fremme recovery (1).

\section{Bør det være nulltoleranse?}

Sidemisbruk anbefales ikke ved legemiddelassistert rehabilitering (LAR), men kan null sidemisbruk forventes? 
Recke påpeker faglige overveielser hva gjelder forutsetninger for forståelse og formidling av LAR og recovery, og legger til at forventningene bør endres til noe som er mer overkommelig for den rusavhengige (9). Forskere støtter riktignok dette og fremhever den gode relasjonen og samhandlingen mellom personalet og bruker som en viktig del av motivasjonen for recovery (1). Relasjonelle faktorer er viktig for bruker for å kunne identifisere affekter, stabilisere emosjoner og utveksle tanker og følelser (5). Og ikke minst styrke mentaliseringen, slik at fokus faller tilbake på recovery. Fokus på rusbruken har vist seg å være negativt for recovery $(1,9)$.

\section{Rusavhengige har rettigheter}

Arbeidet kvalitetssikres gjennom forskrifter, lovverk og andre retningslinjer, og omhandler blant annet normer, verdier og holdninger $(10,11)$. Rusavhengige har rettigheter på lik linje med andre, blant annet til å motta informasjon knyttet til behandling og rehabilitering av rusmiddelproblemer og avhengighet (12). Lov om kommunale helse- og omsorgstjenester viser til forsvarlige og nødvendige helse- og omsorgstjenester til bruker (13). Personalet og bruker må derfor samhandle, lære å kjenne og forstå hverandre.

Ut fra samme forståelse kan misforståelser forebygges og recovery fremmes, og det er her MBT-M kommer inn. Personalet skal med andre ord møte bruker ut fra hvor individet befinner seg her og nå, vise respekt og trekke inn autonomi (selvbestemmelse). Dette gir grunnlag for relasjonsbygging, god mentalisering og recovery $(2,3)$.

\section{Avhengighet er komplekst}

Rusavhengige kan være fra velfungerende til de aller dårligst fungerende brukerne. Personalet $\mathrm{b} \varnothing \mathrm{r}$ derfor tilby et mangfold av metoder og faglighet, nettopp fordi hvert enkelt individ skal behandles ut fra sin egen lidelse, problemer og behov (2). 


\section{«Rusavhengige kan være fra velfungerende til de aller dårligst fungerende brukerne.»}

I den forbindelse kom rusreformen i 2004, som skulle etablere en tverrfaglig spesialisert behandling av rusavhengige. Reformen skulle gi et henblikk på blant annet rusbehandling i et recoveryperspektiv (14). Recovery i rusreformen omhandler å redusere eller slutte med rusmidler, men det praktiske rundt ideologien samsvarer ikke med virkeligheten, ettersom rusavhengige har utfordringer med abstinenser, skadereduksjon og LAR (9).

Min erfaring er at rusavhengighet er sammensatt og komplekst, slik at hva som er god og riktig behandling, kan være veldig forskjellig. Lovverket er bare normer og verdier som kan fungere som retningslinjer, og at problemløsningene vil komme i etterkant (15).

Et dilemma fra praksis er at rusbehandling tar lang tid, og det er vanskelig å få brukeren til å stå i situasjoner og gjennomføre endringer. Endringene kan omhandle redusering av rusinntak til å bli rusfri. Fokus på andre områder enn rusen, som kan skape motivasjon, vil da være viktig, noe også forskere peker på (7).

\section{Noen er mer utsatt}

Ingen er vaksinert mot å utvikle rusavhengighet. Hvem som helst kan bli rammet. Kompleksitet hva gjelder miljømessige, genetiske, fysiske og nevrologiske forhold, gjør at noen mennesker er mer sårbare. Eksempler på risikofaktorer som kan gjøre mennesker rusavhengige, er alvorlig angst hos barn, traumer, tilknytningsvansker, depresjoner, ubehandlet ADHD, mobbing, spiseforstyrrelser og relasjonsskader (2, 15, 16).

\section{«Ingen er vaksinert mot å utvikle rusavhengighet.»}


Et eksempel fra praksis er hvor bruker har lite tilgang på aktivitet, nettverk og trygghet etter omsorgssvikt fra tidlig barneår. Individet ruser seg for å unngå negativ affekt. Rusen fungerer dermed som en flukt fra hverdagen, for å kontrollere eller redusere smerter eller tomrom. Intervensjonen her kan være å tilføre bruker noe annet enn rusen, men som kan gi samme kontroll eller glede.

\section{Forholdet til brukeren}

Personalet kan også ha problemer med å forholde seg til den rusavhengige, hvilket kan omhandle fordommer, at de ikke helt vet hvordan de skal forholde seg til situasjonen, eller når bruker får et tilbakefall (2). Har vi større toleranse og mer forståelse for andre sykdommer og lidelser enn rusavhengige?

Min erfaring er personalets frykt for misforståelser, sinne og aggresjon i møte med den rusavhengige. Andre føler maktesløshet over hvor lett tilgang det er på rus og usikkerhet knyttet til overdose, mens noen føler likegyldighet.

Likegyldighet og avvisning fra personalet kan bidra til blant annet $\varnothing \mathrm{kt}$ overdose hos bruker. Likegyldighet omhandler at personalet er opptatt av at den rusavhengige skal forandre seg og slutte med rus, $\mathrm{i}$ motsetning til å få mulighet til å giøre noe som er viktig for seg selv som kan skape nysgjerrighet, motivasjon og håp om et meningsfylt liv (17). Ifølge Stendal kan MBT-M bidra til at personalet står i situasjoner som kan være vanskelig og utfordrende, i tillegg til at bruker føler seg trygg og ivaretatt (5).

\section{Affekt og selvregulering}


Rusavhengige strever med impulskontroll og affektregulering, og kan lett miste besinnelsen, bli agiterte og truende. Mentaliseringen svekkes som følge av den høye temperaturen, også ovenfor personalets intensjon og handling (2). Hos noen mennesker er den bakenforliggende årsaken at de har vokst opp uten trygge og gode omsorgspersoner. Tilknytningsvansker kan resultere i hemmet mentaliseringsevne, ettersom individet ikke har fått tilstrekkelig opplæring i å regulere egne følelser (5). Økt mentaliseringsevne kan styrke affekt og selvreguleringen (2).

Rusutløste psykoselidelser og tilstander kan være forbundet med redusert kapasitet i affektregulering. Psykosen gjenkjennes ved at man opplever virkeligheten annerledes enn andre. Sansningen endres slik at man kan høre stemmer eller lyder og ser ting andre ikke opplever. Vrangforestillinger er et annet aspekt, hvilket innebærer at ytre stimuli feiltolkes ut fra indre overbevisning (8).

Et eksempel fra praksis er hvor bruker er overbevist om at personalet snakker nedlatende om ham, og tolker blikk og snakk mellom personalet som en bekreftelse på sin fortolkning. Mentaliseringsevnen reduseres og bruker får en sosial tilbaketrekning fordi verden oppleves kaotisk og uforutsigbar. Samtidig er bruker urolig, støyende og utagerende når personalet henvender seg til ham, og angrep blir det beste forsvar som følge av sterk angst. Å skjerme bruker fra omgivelser er derfor viktig (2).

Min erfaring fra å skjerme bruker fra inntrykk fra omgivelser er at det kan dempe og trygge samt beskytte bruker og personalet fra å bli skadet ved et kommende utbrudd. Når personalet involverer seg emosjonelt og utforsker relasjonen og kommunikasjonen, kan det fremme recovery (5). 


\section{Kan miste kontrollen}

Følelser som usikkerhet, redsel, glede, sorg og savn er noe alle mennesker opplever. Hemmet mentaliseringsevne kan gi utfordringer ved at man tolker verden på måter som undergraver god affektregulering (18). Mine erfaringer er at bruker da kan miste kontrollen over følelsene sine, blir sint og ruse seg. Det i seg selv er et tegn på svekket mentalisering og påfølgende likegyldighet overfor destruktive konsekvenser. Rusmidler kan også bli brukt for å unngå mentalisering av andre for å avlede smertefulle følelser og tilstander ved å forhindre å ta inn over seg virkeligheten (2).

\section{«Gjennom ord og handlinger kan personalet gi en forståelse av å oppleve brukers smerte og fortvilelse.»}

For å bekrefte brukers emosjoner og utvikle større toleranse for sinne og aggresjon må personalet benytte sine empatiske evner for å kommunisere med individets emosjoner $(4,5)$. Gjennom ord og handlinger kan personalet gi en forståelse av å oppleve brukers smerte og fortvilelse. Å bli kjent med sine følelser og reaksjonsmønstre ved håndtering av vanskelige situasjoner vil gi brukeren mestringsfølelse og gjøre ham eller henne mer rustet til å håndtere liknende situasjoner. Entusiasme hos personalet kan også forstyrre mentalisering hos bruker fordi vedkommende føler seg usikker og utrygg (2).

\section{Tidligere erfaringer}

Mange rusavhengige har vokst opp i utrygge miljøer. Noen har opplevd mistillit fra nære relasjoner som gjør det vanskelig å stole på andre (2). For at bruker skal åpne seg overfor meg, med sine følelser og tanker, er det essensielt at individet opplever trygghet og tillit. Det motsatte viser seg ved at bruker lukker seg og holder fast ved negative erfaringer som maler verden utrygg. Brukers forsvarsmekanismer kan gjøre det utfordrende å mentalisere (4). 
Språkbruk og atferd hos bruker må ikke tas personlig i slike situasjoner. Bruker kan da agere ut ifra symptomer som en måte å forsvare seg på. For å skape trygghet og dempe frykt hos individet er det viktig at personalet opptrer profesjonelt og innehar faglig kompetanse (5).

Dette sammenfaller med egen erfaring, hvor bruker har høyt angstnivå og utviser verbal aggresjon i en rusutløst psykose. Gjennom MBT-M møter jeg bruker med en vennlig tilnærming som gir bruker mulighet til trygghet og en god opplevelse av samhandling. Jeg ser at dette kan fremme recovery.

\section{Legg vekt på ressurser}

Rusavhengige ruser seg ofte bort fra vonde følelser. Skam og nederlagsfølelse over stadige tilbakefall kan føre til risiko for overdose. MBT-M har som mål å engasjere bruker til å skape endring på områder etter $\varnothing$ nsker fra individet.

For å fremme recovery er det essensielt å $\varnothing \mathrm{ke}$ mentaliseringsevnen hos bruker, hvilket innebærer å legge vekt på brukers ressurser, ønsker og behov ut fra de mentaliseringsvansker og andre utfordringer vedkommende står i. Gjennom en mentaliseringsbasert miljøterapeutisk holdning stimulerer personalet til å utforske og utdype tanker og følelser som kan lede til motivasjon, håp og mestringsfølelse. Recoveryprosessen vil dermed gradvis fremmes ved at personalet er støttende, empatisk og interessert i å opprettholde relasjonen og forebygge uhensiktsmessig atferd. 
Erfaringsmessig har jeg opplevd MBT-M som stimulerende. På en måte er det hverdagslig og selvfølgelig, samtidig som det kan være vanskelig når russug, ambivalens, sinne og aggresjon er daglige utfordringer. Utfordringen ligger i å opprettholde mentaliseringen når motoverføring oppstår, altså når personalet responderer følelsesmessig på bruker. Likevel ser jeg hvordan MBT-M gjør at personalet kvalitetssikrer, systematisk samarbeider og veileder bruker med små steg som fremmer recovery.

Det ville vært spennende å se hvordan effekten arter seg i et større prosjekt, om MBT-M viser seg å være like fruktbar.

\section{Referanser}

1. Brunelle N, Bertrand K, Landry M, Flores-Aranda J, Petenaude C, Brochu S. Recovery from substance use: Drug-dependent people's experiences with sources that motivate them to change. Drugs-education, prevention and policy. DOI:

$\underline{10.3109 / 09687637.2015 .1021665}$

2. Lossius K. Håndbok i rusbehandling. Oslo:

Gyldendal Akademisk; 2017.

3. Rydén G, Wallroth P. Mentalisering. Oslo: Pax forlag; 2014 .

4. Skårderud F, Sommerfeldt B. Miljøterapiboken. Mentalisering som holdning og handling (MBT-M). Oslo: Gyldendal Akademisk; 2018.

5. Stendal MB. Mentaliseringsbasert miljøterapi kan forebygge aggresjon og vold. Sykepleien. 2018;106(72152) (e-72152). Tilgjengelig fra: https://doi.org/10.4220/Sykepleiens.2018.72152 (nedlastet 04.06.2019).

6. Karterud S. Emosjoner i mentaliseringsbasert terapi (MBT). Tidsskrift for Norsk psykologforening. 2013;5O(8):759-64. 
7. Arefjord N, Karterud S, Lossius K. Mentalisering i rusklinikk. Tidsskrift for Norsk psykologforening. 2014;51(6):461-4.

8. Hummelvoll JK. Helt - ikke stykkevis og delt: psykiatrisk sykepleie og psykisk helse. Oslo: Gyldendal Norsk Forlag; 2012.

9. Recke L. Recoverybegrebet mellom mental sundhed og rus. Tidsskrift for psykisk helsearbeid. 2015;2:162-9.

10. Lov 2. juli $1999 \mathrm{nr}$. 64 om helsepersonell (helsepersonelloven). Tilgjengelig fra: https://lovdata.no/dokument/NL/lov/1999-07-02-64 (nedlastet 04.06.2019).

11. Lov 2. juli 1999 nr. 63 om pasient- og brukerrettigheter (pasient- og brukerrettighetsloven). Tilgjengelig fra: https://lovdata.no/dokument/NL/lov/1999-07-02-63 (nedlastet 04.06.2019).

12. Helsedirektoratet. Behandling og rehabilitering av rusmiddelproblemer og avhengighet. Nasjonal faglig retningslinje for behandling og rehabilitering av rusmiddelproblemer og avhengighet. Oslo: Helsedirektoratet; 2016. Tilgjengelig fra: https://helsedirektoratet.no/retningslinjer/behandlingog-rehabilitering-av-rusmiddelproblemer-ogavhengighet (nedlastet 04.06.2019).

13. Lov 24. juni $2011 \mathrm{nr} .30$ om kommunale helse- og omsorgstjenester (helse- og omsorgstjenesteloven). Tilgjengelig fra:

https://lovdata.no/dokument/NL/lov/2011-06-24-30 (nedlastet 04.06.2019).

14. Rusreformen - pasientrettigheter og endringer $\mathrm{i}$ spesialisthelsetjenesteloven. Oslo: Helsedepartementet; 2004. Tilgjengelig fra: https://www.regjeringen.no/no/dokumenter/i82004/id4 45634/ (nedlastet 04.06.2019). 
15. Fekjær HO. RUS. Bruk. Motiver. Skader.

Behandling. Forebygging. Historikk. Oslo: Gyldendal Norsk Forlag; 2016.

16. Hauge R. Rus og rusmidler gjennom tidene. Oslo: Universitetsforlaget; 2009.

17. Berg E. Likegyldighetens tvetydighet:

overdosed $\varnothing$ dsfall etter rusmiddelbehandling. Nordic studies on Alcohol and Drugs. 2016;33(2):189-220.

18. Madsen B. Mentalisering gir bedre samhandling. Sykepleien. 2014. DOI:

10.4220/sykepleiens.2014.0146 Tilgjengelig fra: https://sykepleien.no/forskning/2014/10/mentaliseringgir-bedre-samhandling (nedlastet 04.06.2019). 